with a set of shales with thin courses of impure sandstone, we passed up through thin limestones, with coals and a bone-bed, to the ochre-bed, which represents the basal limestone of the Carboniferous Limestone Series in this locality. Thereafter the section comprised the North Greens Limestone, the Vexhim Limestone and Coal, and the Bilston Burn Limestone. This brings us to the base of the Edge Coal Series, which we saw dipping at high angles, and overlain by the Index Limestone. The Upper Limestone group includes the "Extra" Limestone, the Arden Limestone and the Castlecary Limestone. In the Millstone Grit Mr. Macconochie pointed out to us the position of the "Nebraska band," which contains fossils mainly of American types. By means of a graphic vertical section the sequence of the beds and the characteristics of the important horizons were made perfectly clear. The section is a very remarkable one, for, though not much over a mile in length, it exhibits a vertical succession of rocks nearly 4,000 feet in thickness. After lunch, in Polton, we turned up the Esk Valley and followed the path that leads through the glen. This is a very fine example of a post-glacial gorge cut by the river since it was turned out of its old channel by an obstructing mass of boulderclay. The dam of glacial deposits is well seen above the paper mills at Polton. The stream very nearly follows the strike of the Millstone Grit, of which the various lithological facies can be easily studied in the cliffs. At Roslin many of the party availed themselves of the opportunity to visit the well-known chapel, which is a beautiful example of fifteenth century Scottish ecclesiastical architecture.

\title{
REPORT OF AN EXCURSION TO HAREFIELD.
}

$$
\text { APRIL 26TH, I9 } 3 \text {. }
$$

\section{By R. Fane De Salis, B.A., F.G.S.}

About 40 members of the Association and friends assembled at Marylebone for the $\mathrm{I} .55$ train, and reached Denham at 2.20. A pleasant walk of $\mathrm{I} / 2$ miles took the party over the River Colne and along the towpath of the Grand Junction Canal to the British Portland Cement Company's Works. Here Mr. Downes, the Works Manager, took charge, and explained the process of Cement making. He pointed out that the raw material required for both cement and brick manufacture was on the spot and was all utilized - London Clay, sand from the Reading Beds, and Chalk with flints, the latter being placed in the grinding mills with the clay and chalk for 48 hours. Mr. Whitaker pointed out the manner 
Proc. Geol. Assoc., vol. XXV.

Plate 8.

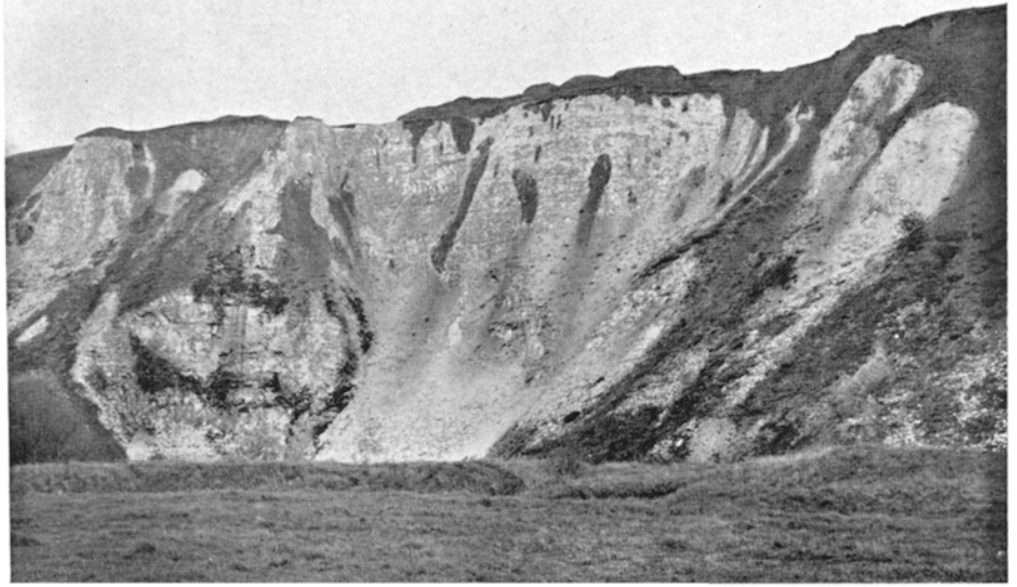

[Photo by $T . W$. Reader.

A.-Part of a large Chalk Pit at Harefield, Midddesex.

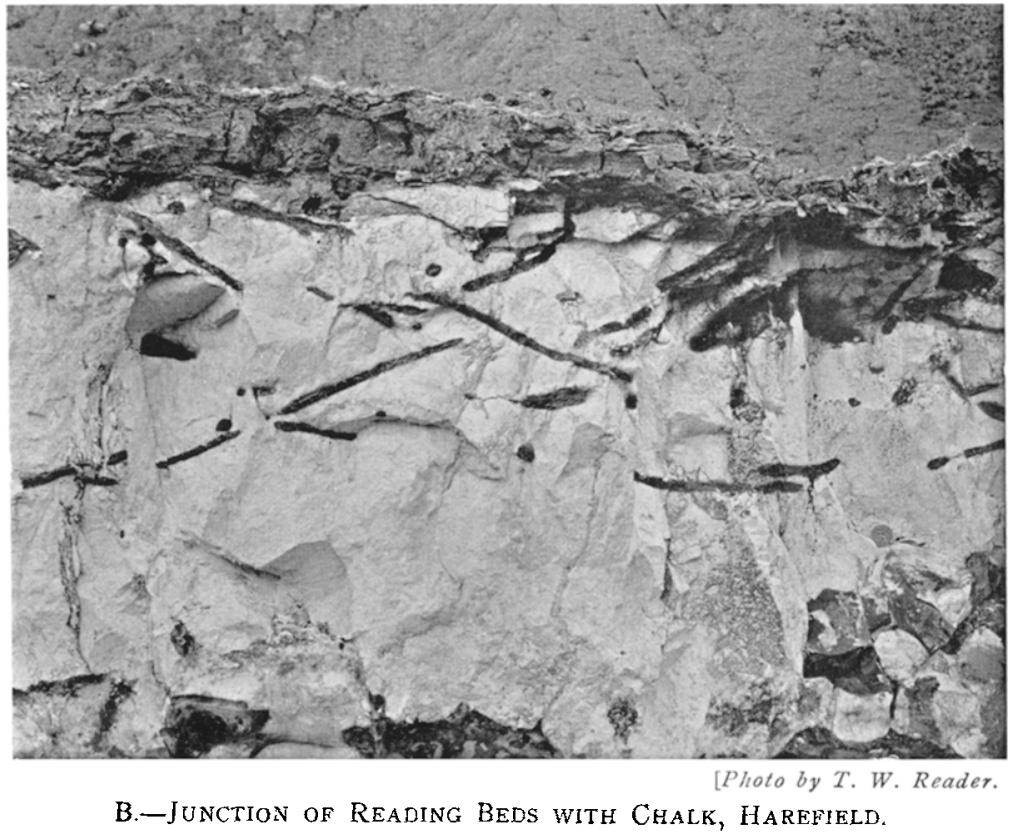

To face page so. 
in which the flints, after grinding, became "pebbles," similar to those found on any beach, the edges were worn off and the stones rounded as if after long rolling in water; the pebbles, after serving their purpose in the mills, are sent by canal to the Potteries to form glaze.

Mr. Whitaker then explained the geology of the exposed face. The Chalk, here, is covered by about 35 feet of the Reading Beds, and on the latter lies the London Clay. The junction of the London Clay and Reading Beds is clearly marked, and here a fair number of fossils were collected. Mr. Whitaker also pointed out that the top layer of chalk was perforated by small irregular borings filled with sand from above. These could be very clearly seen, the borings being about finger-thickness and 6 in. to 9 in. in depth. (Plate 8.B.)

From the Cement Works the party proceeded further up the canal to a Chalk face now being worked by the Bituminous White Co. This face offers a considerable contrast to that previously described, the Chalk here being directly capped with gravel. 'The capping is very irregular being in a set of pipes. The surface of the Chalk slopes down to the Colne valley, and on the sloping face the gravel lies 6 to $8 \mathrm{ft}$. deep. This, Mr. Whitaker pointed out, was probably deposited as downwash after the slopes had been formed, and showed the difficulty of mapping gravel-beds.

The face of the Chalk cutting; which is of considerable extent, is a most excellent example of the power of infiltration to form pipes and potholes. These are in some cases of great depth.and size, and do not descend vertically, but at considerable angles, so much so that in places the face of the Chalk could show an oval bed of gravel, this being a pipe cut in two. The pipes were in every case filled with gravel. Several photographs of this curious formation were obtained by members. (Plate 8.A.)

The party then walked up to Harefield and had tea at Challis' refreshment-rooms.

EXPLANATION OF PLATE 8. By W. WhITAKER, F.R.S.

A.-Shows a part of the great Chalk-pit, showing the very irregular pipes of gravel, from above. These often extend to great depth, sometimes even to the bottom of the pit. Their direction is in some cases so oblique that in the nearly-vertical section they look like more or less roundish masses of gravel included in the Chalk, a very deceptive appearance. Probably these are the finest example of pipes in the Chalk that we have, extending as they do over a great length of section.

B.- This photograph shows the very peculiar and irregular tubes that have been made in about the top 18 in. of the Chalk and filled in with the green sand from the base of the overlying Reading Beds. Sometimes they also contain small green-coated flints from the same bed. It is L.ard to account for them : they seem unlike the work of boring molluscs, which is of a more regular and vertical kind.*

* Hudleston suggested that similar perforations near Reading might be due to the roots of marine plants. Proc. Geol. Assoc, vol. iv, p. 521. H.W.M. 